\title{
Genetic polymorphisms and associated susceptibility to asthma
}

This article was published in the following Dove Press journal:

International Journal of General Medicine

16 April 2013

Number of times this article has been viewed

\author{
Michael E March' \\ Patrick MA Sleiman' \\ Hakon Hakonarson ${ }^{1,2}$ \\ 'Center for Applied Genomics, \\ Abramson Research Center of \\ the Joseph Stokes Jr Research \\ Institute, The Children's Hospital \\ of Philadelphia, ${ }^{2}$ Department of \\ Pediatrics, University of Pennsylvania \\ School of Medicine, Philadelphia, USA
}

Correspondence: Patrick MA Sleiman Hakon Hakonarson

Center for Applied Genomics, I216E Abramson Research Center, 3615 Civic Center Blvd, Philadelphia, PA I9104-4318, USA

$\mathrm{Tel}+\mathrm{I} 2674260088$

Fax +I 2674260363

Email sleimanp@email.cop.edu;

hakonarson@email.cop.edu

\begin{abstract}
As complex common diseases, asthma and allergic diseases are caused by the interaction of multiple genetic variants with a variety of environmental factors. Candidate-gene studies have examined the involvement of a very large list of genes in asthma and allergy, demonstrating a role for more than 100 loci. These studies have elucidated several themes in the biology and pathogenesis of these diseases. A small number of genes have been associated with asthma or allergy through traditional linkage analyses. The publication of the first asthma-focused genome-wide association (GWA) study in 2007 has been followed by nearly 30 reports of GWA studies targeting asthma, allergy, or associated phenotypes and quantitative traits. GWA studies have confirmed several candidate genes and have identified new, unsuspected, and occasionally uncharacterized genes as asthma susceptibility loci. Issues of results replication persist, complicating interpretation and making conclusions difficult to draw, and much of the heritability of these diseases remains undiscovered. In the coming years studies of complex diseases like asthma and allergy will probably involve the use of high-throughput next-generation sequencing, which will bring a tremendous influx of new information as well as new problems in dealing with vast datasets.
\end{abstract}

Keywords: genome-wide association study, high-throughput next-generation sequencing, allergy, environmental irritant, allergen

\section{Introduction}

Asthma is a chronic inflammatory condition of the lungs characterized by excessive responsiveness of the lungs to stimuli in the forms of infections, allergens, and environmental irritants.

Due to the variability of the disease and lack of generally agreed-on standards for diagnosis, it can be difficult to estimate the prevalence of asthma. Further, variations in practice from country to country complicate worldwide estimates. In the USA, it is estimated that at least 22.9 million Americans suffer from the condition. Asthma is the leading chronic illness in US children, with 6.8 million affected in $2006 .{ }^{1}$ It is estimated that 300 million individuals suffer from asthma worldwide, with increased prevalence in both adults and children in recent decades. ${ }^{2}$ Prevalence is rising in locations where rates were previously low and variation in rates from country to country appears to be diminishing. ${ }^{3}$ Twin studies have shown that there is a genetic element to asthma susceptibility, with heritability of the condition estimated at between $36 \%$ and $77 \%{ }^{4-7}$ Since the publication of the first study linking a genetic locus to asthma in 1989, more than 100 candidate genes have been reported in connection to asthma or asthma-related phenotypes such as bronchial hyperresponsiveness and elevated levels 
of serum immunoglobulin (Ig) E. Initial studies were usually candidate-gene analyses, examining the role of specific loci in asthma in a hypothesis-based manner. A few loci were identified in a hypothesis-independent manner through traditional linkage analysis. Recently, the application of genome-wide association (GWA) studies has led to the hypothesis-independent identification of a much larger list of loci associated with asthma.

\section{Functional categories revealed through genetic analyses}

Before describing the loci identified through various study designs, it would be useful to summarize the findings of the last 25 years of genetics research in asthma. The numerous genome-wide linkage, candidate gene, and GWA studies performed on asthma and asthma-related phenotypes have resulted in an increasingly large list of genes implicated in asthma susceptibility and pathogenesis. This list can be categorized into broad functional groups, from which several themes have emerged (reviewed previously ${ }^{8}$ ).

\section{$\mathrm{T}_{\mathrm{H}}$ 2-mediated cell response}

Given the appreciation of asthma as a disease of dysregulated immunity and its connection to atopy and allergic disease, it is perhaps unsurprising that genes controlling the development and regulation of the immune response have been implicated in asthma. $T$ helper $\left(T_{H}\right) 2$ cell-mediated adaptive immune responses have been widely recognized as a crucial component of allergic disease. Pathways involved in $\mathrm{T}_{\mathrm{H}} 2$ cell differentiation and function have been extensively studied in asthma candidategene association studies. Additionally, single nucleotide polymorphisms (SNPs) in many of these genes have been associated with asthma and other allergic phenotypes. Genes important for $\mathrm{T}_{\mathrm{H}} 1$ versus $\mathrm{T}_{\mathrm{H}} 2 \mathrm{~T}$ cell polarization, such as GATA3, TBX21, IL4, IL 4RA, STAT6, and IL12B, have been implicated in asthma and allergy. ${ }^{9-20}$ The genes encoding interleukin (IL)-13 and the beta-chain of the IgE receptor FceR1 are well-replicated contributors to asthma susceptibility. ${ }^{10,12,21-24}$

\section{Inflammation}

Unsurprisingly, several genes involved in inflammation have been associated with asthma. Genes for the cytokine IL-18 $8^{25}$ and its receptor IL18R $1^{26}$ have been implicated, as has the general mediator of inflammation tumor necrosis factor alpha. ${ }^{27}$ Molecular mediators of inflammation have also been implicated, with the identification of leukotriene $\mathrm{C} 4$ synthase and other enzymes involved in the generation of leukotrienes, such as ALOX-5. ${ }^{28-30}$

\section{Environmental sensing and immune detection}

A second class of associated genes is involved in the detection of pathogens and allergens. These genes include patternrecognition receptors and extracellular receptors, such as CD14, toll-like receptor (TLR) 2, TLR4, TLR6, TLR10, and intracellular receptors, such as nucleotide-binding oligomerization domain-containing 1 (NOD1/CARD4). ${ }^{31-36}$ Additional studies have strongly associated variations in the human leukocyte antigen (HLA) class II genes with asthma and allergen-specific IgE responses. ${ }^{21}$

\section{Airway remodeling}

A variety of genes involved in mediating the response to allergic inflammation and oxidant stress on the tissue level appears to be an important contributor to asthma susceptibility. Examples include a disintegrin and metalloproteinase domain-containing protein 33 (ADAM33), which is expressed in lung fibroblasts and smooth muscle cells; the alpha-1 chain of a specific collagen (COL6A5); DPP10, a potentially inactive serine protease; and $G$ protein-coupled receptor for asthma (GPRA), activation of which upregulates metalloprotease expression in the lung. ${ }^{37-40}$

\section{Bronchoconstriction}

Acute asthma episodes involve constriction of the airways. Genes encoding proteins involved in this process have been identified as susceptibility loci for asthma. These loci include CHRNA3/5, which encodes a receptor for acetylcholine; $P D E 4 D$, which encodes a phosphodiesterase with enzymatic activity that generates molecular mediators of smooth muscle cell constriction; and NOS1, which encodes a nitric oxide synthase. ${ }^{41-43}$

\section{Epithelial barrier function}

Studies of asthma genetics have raised new interest in the body's first-line of immune defense, the epithelial barrier, in the pathogenesis of asthma. Mutations in the filaggrin $(F L G)$ gene were initially identified in the rare single-gene disorder ichthyosis vulgaris; ${ }^{44}$ however, loss-of-function variants were reported subsequently to be strongly associated with atopic dermatitis, eczema, and asthma, both dependent on and independent of atopic dermatitis. ${ }^{45-48}$ Filaggrin, a protein involved in keratin aggregation, is not expressed in the bronchial mucosa, ${ }^{49}$ which has led others to suggest that asthma susceptibility in patients with loss-of-function $F L G$ variants may be due to allergic sensitization that occurs after breakdown of the epithelial barrier. ${ }^{50}$ Several epithelial 
genes with important roles in innate and adaptive immune function have also been implicated in asthma. These genes include defensin-betal (DEFB1; an antimicrobial peptide), uteroglobin/Clara cell 16-kD protein (CC16) (an inhibitor of dendritic cell-mediated $\mathrm{T}_{\mathrm{H}}$ 2-cell differentiation), and several chemokines (CCL-5, $-11,-24$, and -26) involved in the recruitment of $\mathrm{T}$ cells and eosinophils. ${ }^{51-57}$

\section{Overview of genetic analyses of asthma}

Most of the published reports examining genetic contributions to asthma have been candidate-gene studies. Over 100 loci have been associated with asthma through candidate-gene studies, in which specific genes are investigated for their involvement in the phenotype based on their suspected roles or plausible hypothetical contributions to disease. The loci identified in candidate-gene studies of asthma and associated phenotypes have been extensively reviewed elsewhere. ${ }^{58-60}$ Among the genes identified in candidate studies are various cytokines and cytokine-signaling proteins involved in $\mathrm{T}$ cell survival, proliferation, and differentiation; genes involved in lung function, development, and response to stimuli; receptors for detection of microbial products; genes involved in epithelial barrier function and innate immunity, ${ }^{48,53}$ and molecules involved in responses to the environment. ${ }^{59,61-63}$ Genes that have been extensively replicated include the beta 2 adrenergic receptor (ADRB2) gene; ${ }^{64-66}$ the cytokines, receptors, signaling proteins, and transcription factors involved in $\mathrm{T}_{\mathrm{H}} 1$ and $\mathrm{T}_{\mathrm{H}} 2$ differentiation of T cells, such as IL4, IL4RA, IFNG, IFNGR1, STAT6, GATA3, and TBX21;,11,14,15,17-20 and genes involved in the cellular responses that characterize atopic disease, such as IL13 and FCER1B. ${ }^{12,13,22-24}$ Many genes identified through candidate-gene studies have failed to be replicated, either because replication has never been attempted or due to failure of replication in subsequent experiments. Failure of replication is a considerable complication in the genetic analysis of asthma. ${ }^{8}$ Genes that have been well replicated in candidate-gene studies examining asthma are summarized in Table 1.

Genome-wide linkage studies rely on families of affected and unaffected individuals and use the differentially shared regions of inherited chromosomes to track genetic markers that segregate with the disease status. Genes within diseaseassociated regions become candidates for further study or for positional cloning of the disease-causing variant. Linkage studies are hypothesis-independent experiments, allowing for the identification of truly novel and previously unsuspected disease-associated variants. Due to the requirement for large family cohorts, genome-wide linkage studies can be difficult and expensive to perform, and are often sufficiently powered to detect only variants with large effects. Linkage studies have identified multiple well-replicated chromosomal regions that contain genes of biological relevance to asthma and allergic disease, including the cytokine cluster on chromosome $5 \mathrm{q}$ (containing IL3, IL5, and granulocyte/macrophage colonystimulating factor [GMCSF]), FCER1B on 11q, interferon $g(I F N G)$ and STAT6 on 12q, and IL4R (the IL-4Ra chain, also part of the IL-13R) on 16p. Linkage studies followed by positional cloning have identified a comparatively small set of novel asthma susceptibility loci, including $C Y F I P 2,{ }^{67}$ DPP 10, ${ }^{68}$ HLAG,${ }^{69}$ PHF $11,{ }^{70}$ GPRA,,${ }^{39}$ and ADAM33. ${ }^{37}$ As molecules with plausible (and potentially drug-targetable) roles in the lung pathology of asthma, GPRA and ADAM33 have generated considerable interest. ${ }^{39}$ Genes identified through genome-wide linkage analyses are summarized in Table 2.

The availability of high-density genotyping arrays and comparatively low costs of applying such technology to increasingly large patient and control cohorts have led to the development of a third kind of genetics experiment: the GWA study. Large numbers of SNPs can be screened in large numbers of individuals and assessed for association with a disease state. As with linkage analyses, GWA studies are hypothesis-independent study designs, allowing the discovery of the contributions of novel loci. Currently, more than 30 GWA studies have been published using asthma, allergy, or related phenotypes such as serum IgE levels or blood eosinophil counts as endpoints. Many of these reports do not report any loci that reach the required level of statistical significance to be considered true GWA results. However, the reports of suggestive associations are valuable, as are reports of failures to replicate previously published results The loci identified through GWA studies that have reached high statistical significance are summarized in Table 3 . This list has grown rapidly in the last few years, as the arrays available for genotyping provide more SNPs for analysis and as researchers collaborate to assemble larger and more completely controlled cohorts to add more statistical power to their analyses.

The first GWA study that focused on bronchial asthma as an endpoint was reported in 2007. ${ }^{71}$ Markers on chromosome 17 q21 were reproducibly associated with childhoodonset asthma. The findings were replicated in German and British cohorts. Independent replication of the 17q21 association has been reported in multiple populations of 
Table I Well-replicated loci identified through candidate-gene studies

\begin{tabular}{|c|c|c|}
\hline Gene & Chromosomal locus & Function \\
\hline ILIO & $|q 3|-q 32$ & Cytokine - immune regulation \\
\hline CTLA4 & $2 q 33$ & Control/inhibition of $\mathrm{T}$ cell responses/immune regulation \\
\hline ILI3 & $5 q 31$ & Induces $T_{\mathrm{H}} 2$ effector functions \\
\hline IL4 & $5 q 31.1$ & $\mathrm{~T}_{\mathrm{H}} 2$ differentiation \\
\hline$C D / 4$ & $5 q 31.1$ & $\begin{array}{l}\text { Microbe detection - recognizes pathogen } \\
\text { associated molecular patterns }\end{array}$ \\
\hline HAVCRI & $5 q 33.2$ & T cell responses - hepatitis $A$ virus receptor \\
\hline LTC4S & $5 q 35$ & Leukotriene synthase - inflammatory mediator \\
\hline LTA & $6 p 21.3$ & Inflammatory mediator \\
\hline TNF & $6 \mathrm{p} 21.3$ & Inflammatory mediator \\
\hline HLA-DRBI & $6 p 21$ & Major histocompatibility complex class II - \\
\hline HLA-DQBI & $6 p 21$ & antigen presentation \\
\hline HLA-DPBI & $6 p 21$ & \\
\hline FCERIB & $1|q| 3$ & Receptor for IgE - atopy \\
\hline ILI8 & $1 \mathrm{lq} 22.2-\mathrm{q} 22.3$ & Inflammation \\
\hline STAT6 & $12 q 13$ & IL-4 and IL-I 3 signaling \\
\hline CMAI & $|4 q| 1.2$ & Chymase - mast cell expressed serine protease \\
\hline IL4R & $|6 p| 2.1-p \mid 2.2$ & Alpha chain of receptors for IL-4 and IL-I3 \\
\hline FLG & Iq2I.3 & Epithelial integrity and barrier function \\
\hline SPINK5 & $5 q 32$ & Epithelial serine protease inhibitor \\
\hline $\mathrm{CCl} / 6$ & $1|q| 2.3-q \mid 3.1$ & $\begin{array}{l}\text { Potential immunoregulatory function - epithelial } \\
\text { expression }\end{array}$ \\
\hline NOSI & $\mid 2 q 24.2-q 24.31$ & Nitric oxide synthase - cellular communication \\
\hline CCLII & $\mid 7 q 21.1-q 21.2$ & Eoxtaxin-I - eosinophil chemoattractant \\
\hline CCL5 & $|7 q| 1.2-q \mid 2$ & $\begin{array}{l}\text { RANTES - chemoattractant for T cells, } \\
\text { eosinophils, basophils }\end{array}$ \\
\hline GSTMI & $|p| 3.3$ & $\begin{array}{l}\text { Detoxification, removal of products } \\
\text { of oxidative stress }\end{array}$ \\
\hline$A D R B 2$ & $5 q 31-q 32$ & Smooth muscle relaxation \\
\hline GPRA & $7 p \mid 4.3$ & $\begin{array}{l}\text { Regulation of metalloprotease expression, } \\
\text { neuronal effects }\end{array}$ \\
\hline NAT2 & $8 p 22$ & Detoxification \\
\hline GSTPI & $|I q| 3$ & $\begin{array}{l}\text { Detoxification, removal of products of } \\
\text { oxidative stress }\end{array}$ \\
\hline ACE & $17 q 23.3$ & Regulation of inflammation \\
\hline$T B X A 2 R$ & $19 p \mid 3.3$ & Platelet aggregation \\
\hline TGFBI & $19 q 13.1$ & $\begin{array}{l}\text { Influences cell growth, differentiation, } \\
\text { proliferation, apoptosis }\end{array}$ \\
\hline ADAM33 & $20 p / 3$ & Cell-cell and cell-matrix interactions \\
\hline GSTTI & $22 q 11.23$ & Detoxification, removal of products of oxidative stress \\
\hline
\end{tabular}

Abbreviations: IgE, immunoglobulin E; IL, interleukin; RANTES, regulated and normal T cell expressed and secreted; $T_{H}$, Thelper.

diverse ethnic backgrounds. ${ }^{72-77}$ This locus contains the genes $O R M D L 3$ and $G S D M B$ and variable expression of both was linked to asthma susceptibility. ${ }^{71}$

A case-control GWA study of North American asthmatics of European ancestry from the Childhood Asthma Management Program (CAMP) cohort has also been reported. The strongest association found was to variants of the PDE4D gene on chromosome $5 \mathrm{q} 12$, which encodes a bronchially expressed phosphodiesterase. ${ }^{42}$ The association of PDE4D to asthma was not observed in individuals of African descent. In a separate study, GWA data from the CAMP cohort was investigated for replication of previously reported candidategene associations. ${ }^{78}$ Thirty-nine genes were investigated with five SNP-based associations replicating to a nominal significance in the IRAK-3, PHF11, IL10, ITGB3, ORMDL3, and $I L 4 R$ genes. Another GWA study on allergic asthma in children 6 years of age has recently been reported. ${ }^{79}$ No single SNP achieved genome-wide significance, but one SNP in an intron of $P D E 11 A$ was cited as potentially interesting. $P D E 11 A$ encodes a phosphodiesterase related to PDE4D, suggesting that this family of proteins may play a broader role in asthma pathogenesis. 
Table 2 Loci identified though linkage studies and positional cloning

\begin{tabular}{lll}
\hline Gene & Chromosomal locus & Reference \\
\hline DPPI0 & $2 q \mid 4.1$ & Allen et al ${ }^{68}$ \\
GPRA & $7 \mathrm{pl} 4.3$ & Laitinen et al ${ }^{39}$ \\
HLAG & $6 \mathrm{p} 21.33$ & Nicolae et al \\
ADAM33 & $20 \mathrm{pl} 3$ & Van Eerdewegh et al ${ }^{37}$ \\
PHFII & $|3 q| 4.3$ & Zhang et al ${ }^{70}$ \\
CYFIP2 & $5 q 33.3$ & Noguchi et al ${ }^{67}$ \\
IRAK3 & $|2 q| 4$ & Balaci et al $\left.\right|^{30}$ \\
COL6A5 & $3 q 2 \mid$ & Söderhäll et al ${ }^{38}$ \\
OPN3/CHML & Iqter & White et al ${ }^{131}$ \\
\hline
\end{tabular}

An association was reported between several SNPs in the transducin-like enhancer of split 4 (TLE4) gene on chromosome $9 \mathrm{q}$ and asthma in a population of 492 Mexican children with asthma, but, again, these associations did not reach genome-wide significance. ${ }^{80}$ However, the investigators replicated these findings in an independent cohort of 177 Mexican case-parent trios. TLE4 had not previously been linked to the pathogenesis of asthma, but does play a role in early B cell development. ${ }^{81}$

Association of asthma with SNPs in multiple genes was reported in a GWA study containing more than 10,000 asthmatics and 16,000 controls. ${ }^{26}$ SNPs in several loci achieved genome-wide significance, including ILIRLI and ILI8R, $H L A-D Q, I L 33, S M A D 3$, and IL2RB. The authors observed association with the previously reported $O R M D L 3 / G S D M B$ locus on chromosome 17 only in childhood-onset asthma. Many of these genes have direct or indirect roles in $\mathrm{T}$ cell responses $(I L 2 R B, H L A-D Q)$ and the development of $\mathrm{T}_{\mathrm{H}} 1$ (IL18RI) or $\mathrm{T}_{\mathrm{H}} 2$ (IL33) responses.

A GWA study from our group was recently reported on a series of pediatric asthma patients consisting of North American cases of European ancestry with persistent asthma requiring daily inhaled glucocorticoids for symptom control, and matched controls without asthma ${ }^{82}$ In this study, in addition to the previously reported $17 \mathrm{q} 21$ locus, we uncovered association to a novel asthma locus on chromosome 1q31. The locus contains $D E N N D 1 B$, a gene that is expressed by natural killer cells and dendritic cells. The association of DENNDIB with asthma replicated in a cohort of African Americans, although the associated allele at each SNP was the alternative allele to that associated with asthma in the discovery set. Allele reversal at shared-risk loci can be attributed to differences in the underlying genomic architecture at the loci between populations of different ancestry. The DENND1B gene has since been replicated in Crohn's disease $^{83}$ and in primary biliary cirrhosis. ${ }^{84}$
A GWA study examining pediatric asthma in a Japanese discovery cohort and Japanese and Korean replication cohorts recently confirmed the role of the HLA locus in these populations. ${ }^{85}$ Additionally, this study identified TSLP on chromosome 5, along with a gene-rich region on chromosome 12 and the USP38-GAB1 region on chromosome 4.

Four loci were identified in a GWA study that examined Australian cases and controls in combination with large numbers of genotyped samples from the GABRIEL (A Multidisciplinary Study to Identify the Genetic and Environmental Causes of Asthma in the European Community) Consortium and multiple in silico cohorts ${ }^{86}$ Reported statistically significant loci were IL6R on chromosome 1, C11orf30/LRRC32 on chromosome 11, PRKG1 on chromosome 10, and RPL32P28/ OR7E156P on chromosome 13. The locus on chromosome 11 was also associated with atopy among asthmatics.

A recent meta-analysis examined three ethnically diverse North American populations (European American, African American or African Caribbean, and Latino), searching for asthma susceptibility loci that replicated across ethnic cohorts. ${ }^{87}$ Four previously identified loci were identified in this study (17q21, IL1RL1, TSLP, IL33), although this is the first report that has shown they are shared across three ethnic groups. Additionally, the PYHIN1 locus was identified as a new susceptibility locus in African Americans.

Several GWA studies have been reported using intermediate phenotypes and quantitative traits, rather than asthma itself, as study endpoints. The first report used GWAs to identify variants that modulate serum protein levels. ${ }^{88}$ A promoter SNP in the CHI3L1 gene that encodes the chitinase-like protein YKL-40 was shown to influence serum YKL-40 levels and to be weakly associated with asthma, bronchial responsiveness, and pulmonary function in the Hutterite population. A GWA study showed significant association of the FCER1A and RAD50 genes with expression of CHI3L1, and evidence for association of the STAT6 gene with IgE levels. IgE levels are closely correlated with the clinical expression and severity of both asthma and allergy. The RAD50 variants were further shown to be associated with increased risk of asthma and atopic eczema. ${ }^{89}$ Several loci (IL4R, FCER1A, IL13, STAT6, and HLA) with known functions in $\mathrm{T}_{\mathrm{H}} 2$ and allergic responses were associated with IgE levels in another recent GWA study. ${ }^{90}$

Eosinophils are leukocytes that play an important role in the initiation and propagation of inflammatory signals. This makes them probable mediators of inflammatory disease and a GWA study was performed examining blood eosinophil counts. ${ }^{91}$ 
Table 3 Genome-wide association study loci referenced in this review

\begin{tabular}{|c|c|c|c|c|}
\hline Reported gene & Locus & $\begin{array}{l}\text { Top single nucleotide } \\
\text { polymorphism }\end{array}$ & Endpoint analyzed & Reference \\
\hline ORMDL3 & $17 q 12$ & rs7216389 & Asthma & Moffatt et $\mathrm{al}^{71}$ \\
\hline CHI3LI & Iq32.1 & rs4950928 & Asthma/YKL-40 serum levels & Ober et $\mathrm{a}^{88}$ \\
\hline ILIRLI & $2 q 12.1$ & rsI42010I & Asthma/blood & Gudbjartsson et $\mathrm{al}^{91}$ \\
\hline IKZF2 & $5 q 31.1$ & rs 12619285 & Eosinophil count & \\
\hline GATA2 & $3 q 21.3$ & rs4857855 & & \\
\hline IL5 & $2 q \mid 2.1$ & rs4I43832 & & \\
\hline $\mathrm{SH} 2 \mathrm{~B} 3$ & $12 q 24.12$ & rs3184504 & & \\
\hline TLE4 & $9 q 21.31$ & rs2378383 & Asthma & Hancock et a ${ }^{80}$ \\
\hline PDE4D & $5 q \mid 2.1$ & rsI588265 & Asthma & Himes et $\mathrm{a}^{42}$ \\
\hline PDEIIA & $2 q 31.2$ & rsII684634 & Asthma & DeWan et $\mathrm{al}^{79}$ \\
\hline RAD50 & $5 q 31.1$ & rs22440I2 & Asthma & Li et $\mathrm{a}^{21}$ \\
\hline$H L A-D R / D Q$ & $6 p 21.32$ & rs3998I59 & & \\
\hline$A D R A / B$ & $5 q 33$ & rs 10515807 & Asthma & Mathias et $\mathrm{al}^{132}$ \\
\hline PRNP & $20 p / 2$ & rs605276I & & \\
\hline DPPIO & $12 q \mid 2.3$ & rs 1435879 & & \\
\hline ILIRLI/ILI8RI & $2 q \mid 2.1$ & rs377II 66 & Asthma & Moffatt et $\mathrm{al}^{26}$ \\
\hline HLA-DQ & $6 p 21.32$ & rs9273349 & Childhood-onset asthma & \\
\hline IL33 & $9 p 24.1$ & rsI342326 & & \\
\hline SMAD3 & $15 q 22.33$ & rs744910 & & \\
\hline IL2RB & $22 q \mid 2.3$ & rs2284033 & & \\
\hline ORMDL3/GSDMB & $17 q 12$ & rs2305480 & & \\
\hline HLA-DPA I/HLA-DPB I & $6 p 21.3$ & rs987870 & Pediatric asthma & Noguchi et al $\left.\right|^{133}$ \\
\hline DENNDIB & $|q 3| .3$ & rs2786098 & Pediatric asthma & Sleiman et $\mathrm{al}^{82}$ \\
\hline IL6R & $|\mathrm{q} 2| .3$ & rs4I29267 & Asthma & Ferreira et $\mathrm{al}^{86}$ \\
\hline CII orf30/LRRC32 & $|I q| 3.5$ & rs7|30588 & & \\
\hline USP38-GABI & $4 q 31$ & rs7686660 & Asthma & Hirota et a $\left.\right|^{85}$ \\
\hline TSLP/WDR36 & $5 q 22$ & rs 1837253 & & \\
\hline NOTCH4/HLA-DRA/ & $6 p 21.32$ & rs404860 & & \\
\hline HLA-DQA2/IKZF4 & $6 p 21.32$ & rs404860 & & \\
\hline LOC33859I & $10 p \mid 4$ & rs 10508372 & & \\
\hline IKZF4/CDK2 & $12 q 13$ & rsI701704 & & \\
\hline GSDMB & $17 q 12$ & rsIII078927 & Asthma in four ethnically & Torgerson et $\mathrm{a}^{87}$ \\
\hline ILIRLI & $2 q \mid 2.1$ & rs $1017308 \mid$ & diverse North American & \\
\hline TSLP & $5 q 22.1$ & rs 1837253 & populations & \\
\hline IL33 & $9 p 24.1$ & $r s 2381416$ & & \\
\hline PYHINI & Iq23.1 & rsII02000 & & \\
\hline CI lorfl I & IIq23.2 & rsII214966 & & \\
\hline CRCTI & $\mid q 21.3$ & rs4845783 & & \\
\hline ORMDL3 & $17 q 12$ & rs6503525 & Asthma & Ferreira et $\mathrm{al}^{77}$ \\
\hline CI lorf30/LRRC32 & $|\mathrm{Iq}| 3.5$ & rs2155219 & Allergic rhinitis/grass & Ramasamy et $\mathrm{a}^{90}$ \\
\hline TMEM232/SLCA25A46 & $5 q 22.1$ & rs 17513503 & sensitization & \\
\hline HLA region & $6 p 21$ & rs7775228 & & \\
\hline FCERIA & Iq23.2 & rs2251746 & IgE levels & Granada et al $\left.\right|^{134}$ \\
\hline ILI3 & $5 q 31.1$ & rs2054l & & \\
\hline HLA-A & $6 p 22.1$ & rs257|39| & & \\
\hline STAT6/NAB2 & $12 q \mid 3.3$ & rs 1059513 & & \\
\hline DARC & Iq23.2 & rs 13962 & & \\
\hline HLA-DQA2 & $6 p 21.32$ & rs285833I & & \\
\hline FCERIA & Iq23.2 & rs2427837 & Serum IgE levels & Weidinger et $\mathrm{a}^{89}$ \\
\hline STAT6 & $12 q 13$ & rs 12368672 & & \\
\hline RAD50 & $5 q 31.1$ & rs2706347 & & \\
\hline CHRNA3/5 & $15 q 24$ & rs8034191 & COPD & Pillai et al $\left.\right|^{135}$ \\
\hline FAM $/ 3 A$ & $4 q 22.1$ & rs767II67 & COPD & Cho et $\mathrm{al}^{136}$ \\
\hline RAB4B/EGLN2/MIA/CYP2A6 & $19 q 13$ & rs7937 & COPD & Cho et $\mathrm{al}^{137}$ \\
\hline HHIP & $4 q 31.22$ & rs|3|47758 & $\mathrm{FEV}_{1} / \mathrm{FVC}$ & Wilk et $\mathrm{a}^{92}$ \\
\hline
\end{tabular}


Table 3 (Continued)

\begin{tabular}{|c|c|c|c|c|}
\hline Reported gene & Locus & $\begin{array}{l}\text { Top single nucleotide } \\
\text { polymorphism }\end{array}$ & Endpoint analyzed & Reference \\
\hline HHIP & $4 q 31.22$ & rs| 980057 & $\mathrm{FEV}_{1} / \mathrm{FVC}$ & Hancock et al ${ }^{93}$ \\
\hline GPR/26 & $6 q 24.1$ & rs3817928 & $\mathrm{FEV} / \mathrm{FVC}$ & \\
\hline ADAM 19 & $5 q 33$ & rs2277027 & $\mathrm{FEV}_{1} / \mathrm{FVC}$ & \\
\hline AGER-PPT2 & $6 \mathrm{p} 21.3$ & rs2070600 & $\mathrm{FEV}_{1} / \mathrm{FVC}$ & \\
\hline FAM $/ 3 A$ & $4 q 22.1$ & rs2869967 & $\mathrm{FEV}_{1} / \mathrm{FVC}$ & \\
\hline PTCHI & $9 q 22.32$ & rsl6909898 & $\mathrm{FEV}_{1} / \mathrm{FVC}$ & \\
\hline PID I & $2 q 36.3$ & rs|435867 & $\mathrm{FEV}_{1} / \mathrm{FVC}$ & \\
\hline HTR4 & $5 q 33.1$ & rslll 68048 & $\mathrm{FEV}_{1} / \mathrm{FVC}$ & \\
\hline INTSI 2-GSTCD-NPNT & $4 q 24$ & rs 17331332 & $\mathrm{FEV}_{1}$ & \\
\hline TNSI & $2 q 35$ & rs257|445 & $\mathrm{FEV}_{1}$ & Repapi et al ${ }^{94}$ \\
\hline GSTCD & $4 q 24$ & rs10516526 & $\mathrm{FEV}_{1}$ & \\
\hline HHIP & $4 q 31.22$ & rs 12504628 & $\mathrm{FEV}_{1} / \mathrm{FVC}$ & \\
\hline HTR4 & $5 q 33.1$ & rs3995090 & $\mathrm{FEV}_{\text {, }}$ & \\
\hline$A G E R$ & $6 p 21.32$ & rs2070600 & $\mathrm{FEV}_{1} / \mathrm{FVC}$ & \\
\hline THSD 4 & $15 q 23$ & rs 12899618 & $\mathrm{FEV}_{1} / \mathrm{FVC}$ & \\
\hline MFAP2 & $1 \mathrm{p} 36.13$ & rs2284746 & $\mathrm{FEV}_{1} / \mathrm{FVC}$ & Soler Artigas et al ${ }^{138}$ \\
\hline TGFB2 & $|q 4|$ & rs993925 & $\mathrm{FEV}_{1} / \mathrm{FVC}$ & \\
\hline HDAC4 & $2 q 37.3$ & rs $124773 \mid 4$ & $\mathrm{FEV}_{1} / \mathrm{FVC}$ & \\
\hline RARB & $3 p 24$ & rsI529672 & $\mathrm{FEV}_{1} / \mathrm{FVC}$ & \\
\hline MECOM & $3 q 26$ & rsI344555 & $\mathrm{FEV}_{1}$ & \\
\hline SPATA9 & $5 q 15$ & rs 153916 & $\mathrm{FEV}_{1} / \mathrm{FVC}$ & \\
\hline ZKSCAN3 & $6 p 22.1$ & rs6903828 & $\mathrm{FEV}_{1}$ & \\
\hline NCR3 & $6 \mathrm{p} 21.3$ & rs2857595 & $\mathrm{FEV}_{1} / \mathrm{FVC}$ & \\
\hline ARMC2 & $6 q 21$ & rs279864I & $\mathrm{FEV}_{1} / \mathrm{FVC}$ & \\
\hline ClOorfl I & $10 q 22.2$ & rsl1001819 & $\mathrm{FEV}_{1}$ & \\
\hline$L R P I$ & $12 q 13.3$ & rsIII72II3 & $\mathrm{FEV}_{1} / \mathrm{FVC}$ & \\
\hline CCDC38 & $12 q 23.1$ & rs1036429 & $\mathrm{FEV}_{1} / \mathrm{FVC}$ & \\
\hline MMPI5 & 16q21 & rs 12447804 & $\mathrm{FEV}_{1} / \mathrm{FVC}$ & \\
\hline CFDPI & $16 q 23.1$ & rs286553I & $\mathrm{FEV}_{1} / \mathrm{FVC}$ & \\
\hline KCNE2 & $21 q 22.1$ & rs9978I42 & $\mathrm{FEV}_{1} / \mathrm{FVC}$ & \\
\hline DLEU7 & $|3 q| 4.3$ & rs9316500 & $\mathrm{FEV}_{1}$ & Imboden et al $\left.\right|^{139}$ \\
\hline
\end{tabular}

Abbreviations: COPD, chronic obstructive pulmonary disease; $\mathrm{FEV}_{\mathrm{I}}$, forced expiratory volume in I second; FVC, forced vital capacity; IgE, immunoglobulin $\mathrm{E}$.

Five loci reached GWA significance, one of which, IL1RL1, was also shown to be associated with asthma in a collection of ten different populations.

Altered lung function, and airflow obstruction in particular, is associated with both asthma and chronic obstructive pulmonary disease. Two SNPs at the $\alpha$-nicotinic acetylcholine receptor (CHRNA3/5) surpassed genome-wide significance in the study and replicated in two of three independent cohorts. The authors also reported that SNPs at the HHIP locus on chromosome 4 showed association and were consistently replicated across the study cohorts but did not reach genome-wide significance. ${ }^{41}$ In the first of the three lung-function GWA studies that included 7691 Framingham Heart Study participants, the only locus to surpass genome-wide significance for association with forced expiratory volume in 1 second/forced vital capacity ratio and replicate in an independent cohort of 835 Family Heart Study participants was HHIP. ${ }^{92}$ Two studies resulted in the identification of eleven novel loci associated with measures of lung function; both studies also replicated the previously reported association of the HHIP locus. ${ }^{93,94}$

\section{The future of asthma genetics New technology}

As the technologies that exist for the identification of genetic variants and the analysis of those variants continue to evolve, the information dealing with the effects of genetic variations on the development of and susceptibility to asthma will grow at a rapidly increasing pace. The advent of next-generation sequencing is bringing complete sequences of genomes and exomes into the public domain. High-throughput sequencing will allow the identification of rare variants with minor allele frequencies far too low to be captured with array technologies that contribute to complex common diseases like asthma. An excellent recent report used targeted sequencing of nine candidate genes to discover rare variants in those loci that 
associate with asthma. ${ }^{95}$ The authors show evidence for the probable existence of rare variants that associate with asthma and identify variants in the ILI2RBI locus that contribute to asthma susceptibility in Americans of both European and African ancestries. Many of the associated variants were unexpectedly found in noncoding regions of these genes, indicating that regulation of the genes plays a crucial role in disease susceptibility. Future efforts that include whole exome and whole genome sequencing will greatly expand this type of information, while bringing the considerable challenge of identifying which variants in an individual are relevant for the diseases being studied.

An additional factor to consider is the issue of uncharacterized genes. Many of the most recent GWA studies have identified loci associated with asthma containing genes that have either no known function or no known function that is easily correlated with the disease phenotype. Genes involved in the development of the immune system or specifically in the skewing of the immune response towards or away from an allergic phenotype have obvious implications for asthma susceptibility or severity. However, genes are now being identified with no obvious connections to asthma. The $D E N N D 1 B^{82}$ and $O R M D L 3^{26}$ loci are examples of genes that are difficult to connect to asthma-related phenotypes. Additionally, the list of loci in Table 3 includes several loci corresponding to completely uncharacterized genes with no known function (c1lorf30/ LRRC32), ${ }^{86,90}$ (c11orf71), ${ }^{87}$ (GPR126), ${ }^{93}$ (c10or11), ${ }^{138}$ or to pseudogenes (LOC338591) ${ }^{85}$ reported to be unexpressed. A sizeable effort will be required to understand how these genes contribute to asthma and it remains to be seen if researchers will undertake such challenges and if institutes and agencies will provide funding for this kind of work.

\section{Gene-environment interactions}

Asthma, as an immune-mediated disease, involves the response of the body to the environment, in the form of pollutants, allergens, viruses, and other pathogens and irritants. These environmental factors interact with genetic variation to influence the development or severity of disease. Researchers are finding that specific genetic variants affect susceptibility to, and the severity of, asthma in different ways depending on the environments of the individuals carrying those variants, a phenomenon known as "gene-environment interaction." Several examples of gene-environment interaction exist in asthma, with perhaps the best characterized being CD14, which was originally associated with asthma in linkage studies. ${ }^{96-100} \mathrm{~A}$ polymorphism in the $C D 14$ promoter was associated with increased $\mathrm{CD} 14$ protein levels in serum and reduced serum IgE levels. ${ }^{101,102}$ Several studies attempted to associate this polymorphism with asthma, with conflicting results. ${ }^{103-109}$ These conflicts were resolved when the polymorphism was considered in the context of environmental influences. Different alleles of the CD14 promoter were associated with allergic phenotypes in children, depending on the type of pets or animals to which the children were exposed. One allele correlated with higher IgE levels in children exposed to household pets such as cats and dogs, while the other allele associated with the same phenotype in children exposed to stable animals like horses. ${ }^{110}$ Homozygotes for one allele were found to be at lower risk for asthma if exposed to comparatively low levels of house dust endotoxin but at higher risk at higher endotoxin exposures. ${ }^{111}$ Other polymorphisms at the CD14 locus have been associated with different outcomes in specific populations, depending on environmental exposure. ${ }^{105}$ Given the large number of identified asthma susceptibility loci and the daunting number of environmental variables that may influence complex diseases, much work remains to be done before we have a reasonable understanding of the roles of gene-environment interactions in asthma.

\section{Gene-gene interactions}

A comparatively small number of studies have been published to date examining the role in asthma of gene-gene interactions, where variation at one locus alters the effects of variations at a second locus, reflecting epitasis between two or more genes. The existing literature consists mainly of studies in which researchers have chosen two or more specific genes (and occasionally specific variants of those genes) to examine in the context of asthma, looking for evidence of interactions between the two loci. Examples of gene-gene interactions that have been observed in association with asthma include $I L 9$ and $I L 9 R$ polymorphisms in Koreans, ${ }^{112}$ TGFBR 2 and FOXP3 in specific $\operatorname{IgE}$ production, ${ }^{113} I L 13$ and IL4 in Dutch cohorts, ${ }^{114}$ and LTA4H and ALOX5 AP in Latinos. ${ }^{30}$ Larger scale analysis examining 169 SNPs in 29 genes identified a number of gene-gene interactions affecting both total and antigen-specific $\operatorname{IgE}$ levels. ${ }^{115}$ Methods are actively being developed to enable large scale and unbiased analysis of gene-gene interactions ${ }^{116}$ and visualization of the resulting networks, ${ }^{117}$ but these efforts are in their relative infancy. Given the number of previously identified relevant genes and the possibilities for discovery of new loci, the combinatorial potential for interactions between gene effects is daunting. Much development of methods and tools remains to be done before we can truly grasp these vast possibilities. 


\section{Pharmacogenetics}

Pharmacogenetics, in which variations in genotype are examined for their effects on the response to treatments, is of growing interest with asthma, with the hope that it will increase efficacy and reduce toxic side effects of medications. The best example at this time is provided by beta-adrenergic receptor agonists (or simply beta-agonists), which are prescribed to treat bronchoconstriction and provide long-term symptom control for asthmatics. The ARDB2 locus encodes the beta ${ }_{2}$-adrenergic receptor, which binds to and is activated by beta-agonists. Two studies have implicated variations in $A R D B 2$ as modulators of response to inhaled bronchodilators. ${ }^{118,119}$ However, a randomized double-blind study was performed in which subjects were genotyped before being enrolled so that they could be stratified by genotype before receiving prescriptions. ${ }^{120}$ This study showed no association of genotype with the response to beta-agonists. Another study showed that a polymorphism in the ARDB2 protein influences the response to regularly administered albuterol, with one genotype receiving less relief from regular longterm use of short-acting beta-agonists. ${ }^{121}$ Yet another group has shown that genotype at $A R D B 2$ does not affect the response to combined beta-agonist and inhaled corticosteroid treatment. ${ }^{122}$

A recent study identified variants in the promoter of the GLCCI1 gene that are associated with reduced responses to inhaled glucocorticoids. ${ }^{123}$ A specific promoter variant was found to possess reduced transcriptional activity in reporter assays. The same variant was associated with reduced changes in lung function following glucocorticoid treatment. The authors calculate that this variant accounts for about $6.6 \%$ of the variability in inhaled glucocorticoid responses. Another recent publication reports variants in the low affinity $\operatorname{IgE}$ receptor gene, FCER2, associated with severe exacerbations in children in a trial of inhaled glucocorticoids. The association was present in both European Americans and African Americans and one of the polymorphisms correlated with reduced FCER 2 expression. Variants have been identified that alter the response to a 5-lipoxygenase inhibitor $^{124}$ and that associate with variability in the response to a cysteinyl leukotriene receptor 1 antagonist. ${ }^{125}$ Polymorphisms in corticotrophin-releasing hormone receptor $(C R H R 1)^{126}$ and the STIP1 gene (involved in the signaling initiated by glucocorticoids) ${ }^{127}$ associate with variable forced expiratory volume in 1 second response after inhaled glucocorticoid treatment, as do polymorphisms in $T B X 21$, encoding a transcription factor important in the generation of $\mathrm{T}_{\mathrm{H}} 1$ cells. ${ }^{19}$ This latter study demonstrates that variations in genes not directly involved in the metabolism or signaling cascades of a drug can be important modulators of the response to that drug. New study designs and analysis techniques will be required if the pharmacogenetics field is to be able to account for all the variables that may contribute to variable responses to therapies.

\section{Conclusion}

Considerable challenges remain in our understanding of the genetic underpinnings of asthma. The incredibly large quantity of data collected to date only explains a fraction of the heritability of asthma. This missing heritability is a common problem in the genetics of complex diseases. Future GWA studies may fill some of the gap in knowledge, although GWA studies are best suited to finding relatively common alleles of modest effect sizes. The use of next-generation sequencing in complex disease research may bring the identification of rare variants with larger effects, which will likely explain at least some of the missing heritability. Additionally, techniques for studying epigenetic phenomena, such as DNA methylation, have the power to expand our understanding of the causes of asthma. Recently, variations in DNA methylation in transformed B cells were described at a specific locus in a specific subset of asthmatics. ${ }^{128}$ Variations, including methylation, in the promoter of the Prostaglandin D2 receptor gene, were reported in cohorts of asthmatic and atopic individuals. ${ }^{129}$ It is probable that many more epigenetic variations, in a variety of cell types relevant to the development, severity, and treatment of asthma, will be reported in the near future. The expanded genetic and epigenetic information from future studies, combined with improved understanding and analysis of gene-gene and gene-environment interactions are likely to fill many of the gaps in our current understanding and allow us to improve the care we provide to asthma sufferers.

\section{Disclosure}

The authors declare no conflicts of interest in this work.

\section{References}

1. American Lung Association. Lung Disease Data: 2008. New York, NY: American Lung Association; 2008. Available from: http://www.lung. org/assets/documents/publications/lung-disease-data/LDD_2008.pdf. Accessed January 7, 2012.

2. Masoli M, Fabian D, Holt S, Beasley R; Global Initiative for Asthma (GINA) Program. The global burden of asthma: executive summary of the GINA Dissemination Committee report. Allergy. 2004;59(5):469-478.

3. Pearce N, Aït-Khaled N, Beasley R, et al; ISAAC Phase Three Study Group. Worldwide trends in the prevalence of asthma symptoms: phase III of the International Study of Asthma and Allergies in Childhood (ISAAC). Thorax. 2007;62(9):758-766. 
4. Duffy DL, Martin NG, Battistutta D, Hopper JL, Mathews JD. Genetics of asthma and hay fever in Australian twins. Am Rev Respir Dis. 1990;142(6 Pt 1):1351-1358.

5. Harris JR, Magnus P, Samuelsen SO, Tambs K. No evidence for effects of family environment on asthma. A retrospective study of Norwegian twins. Am J Respir Crit Care Med. 1997;156(1):43-49.

6. Koppelman GH, Los H, Postma DS. Genetic and environment in asthma: the answer of twin studies. Eur Respir J. 1999;13(1):2-4.

7. Nieminen MM, Kaprio J, Koskenvuo M. A population-based study of bronchial asthma in adult twin pairs. Chest. 1991;100(1):70-75.

8. Bossé Y, Hudson TJ. Toward a comprehensive set of asthma susceptibility genes. Ann Rev Med. 2007;58:171-184.

9. Basehore MJ, Howard TD, Lange LA, et al. A comprehensive evaluation of IL4 variants in ethnically diverse populations: association of total serum IgE levels and asthma in white subjects. JAllergy Clin Immunol. 2004;114(1):80-87.

10. Genuneit J, Cantelmo JL, Weinmayr G, et al; ISAAC Phase 2 Study Group. A multi-centre study of candidate genes for wheeze and allergy: the International Study of Asthma and Allergies in Childhood Phase 2. Clin Exp Allergy. 2009;39(12):1875-1888.

11. Haller G, Torgerson DG, Ober C, Thompson EE. Sequencing the IL4 locus in African Americans implicates rare noncoding variants in asthma susceptibility. J Allergy Clin Immunol. 2009;124(6):1204-1209. e1209.

12. Howard TD, Koppelman GH, Xu J, et al. Gene-gene interaction in asthma: IL4RA and IL13 in a Dutch population with asthma. Am J Hum Genet. 2002;70(1):230-236.

13. Kabesch M, Schedel M, Carr D, et al. IL-4/IL-13 pathway genetics strongly influence serum IgE levels and childhood asthma. J Allergy Clin Immunol. 2006;117(2):269-274.

14. Munthe-Kaas MC, Carlsen KH, Haland G, et al. T cell-specific T-box transcription factor haplotype is associated with allergic asthma in children. J Allergy Clin Immunol. 2008;121(1):51-56.

15. Pykäläinen $M$, Kinos R, Valkonen S, et al. Association analysis of common variants of STAT6, GATA3, and STAT4 to asthma and high serum IgE phenotypes. J Allergy Clin Immunol. 2005;115(1): $80-87$.

16. Raby BA, Hwang ES, Van Steen K, et al. T-bet polymorphisms are associated with asthma and airway hyperresponsiveness. Am J Respir Crit Care Med. 2006;173(1):64-70.

17. Randolph AG, Lange C, Silverman EK, et al. The IL12B gene is associated with asthma. Am J Hum Genet. 2004;75(4):709-715.

18. Suttner K, Rosenstiel P, Depner M, et al. TBX21 gene variants increase childhood asthma risk in combination with HLX1 variants. J Allergy Clin Immunol. 2009;123(5):1062-1068, 1068. e1-e8.

19. Tantisira KG, Hwang ES, Raby BA, et al. TBX21: a functional variant predicts improvement in asthma with the use of inhaled corticosteroids. Proc Natl Acad Sci U S A. 2004;101(52):18099-18104.

20. Zhou H, Hong X, Jiang S, Dong H, Xu X. Analyses of associations between three positionally cloned asthma candidate genes and asthma or asthma-related phenotypes in a Chinese population. BMC Med Genet. 2009; 10:123.

21. Li X, Howard TD, Zheng SL, et al. Genome-wide association study of asthma identifies RAD50-IL13 and HLA-DR/DQ regions. J Allergy Clin Immunol. 2010;125(2):328-335. e311.

22. Potaczek DP, Nishiyama C, Sanak M, Szczeklik A, Okumura K. Genetic variability of the high-affinity IgE receptor alpha-subunit (FcepsilonRIalpha). Immunol Res. 2009;45(1):75-84.

23. Vladich FD, Brazille SM, Stern D, Peck ML, Ghittoni R, Vercelli D. IL-13 R130Q, a common variant associated with allergy and asthma, enhances effector mechanisms essential for human allergic inflammation. J Clin Invest. 2005;115(3):747-754.

24. Wu X, Li Y, Chen Q, et al. Association and gene-gene interactions of eight common single-nucleotide polymorphisms with pediatric asthma in middle China. J Asthma. 2010;47(3):238-244.

25. Thompson SR, Humphries SE. Interleukin-18 genetics and inflammatory disease susceptibility. Genes Immun. 2007;8(2):91-99.
26. Moffatt MF, Gut IG, Demenais F, et al; GABRIEL Consortium. A large-scale, consortium-based genomewide association study of asthma. N Engl J Med. 2010;363(13):1211-1221.

27. Lykouras D, Sampsonas F, Kaparianos A, Karkoulias K, Spiropoulos K. Role and pharmacogenomics of TNF-alpha in asthma. Mini Rev Med Chem. 2008;8(9):934-942.

28. Duroudier NP, Tulah AS, Sayers I. Leukotriene pathway genetics and pharmacogenetics in allergy. Allergy. 2009;64(6):823-839.

29. Sayers I, Barton S, Rorke S, et al. Allelic association and functional studies of promoter polymorphism in the leukotriene C4 synthase gene (LTC4S) in asthma. Thorax. 2003;58(5):417-424.

30. Via M, De Giacomo A, Corvol H, et al. The role of LTA4H and ALOX5AP genes in the risk for asthma in Latinos. Clin Exp Allergy. 2010;40(4):582-589.

31. Eder W, Klimecki W, Yu L, et al; ALEX-Team. Association between exposure to farming, allergies and genetic variation in CARD4/NOD1. Allergy. 2006;61(9):1117-1124.

32. Eder W, Klimecki W, Yu L, et al; ALEX Study Team. Toll-like receptor 2 as a major gene for asthma in children of European farmers. J Allergy Clin Immunol. 2004;113(3):482-488.

33. Hysi P, Kabesch M, Moffatt MF, et al. NOD1 variation, immunoglobulin E and asthma. Hum Mol Genet. 2005;14(7):935-941.

34. Kabesch M, Carr D, Weiland SK, von Mutius E. Association between polymorphisms in serine protease inhibitor, kazal type 5 and asthma phenotypes in a large German population sample. Clin Exp Allergy. 2004;34(3):340-345.

35. Kormann MS, Depner M, Hartl D, et al. Toll-like receptor heterodimer variants protect from childhood asthma. J Allergy Clin Immunol. 2008;122(1):86-92.

36. Smit LA, Siroux V, Bouzigon E, et al; Epidemiological Study on the Genetics and Environment of Asthma, Bronchial Hyperresponsiveness, and Atopy (EGEA) Cooperative Group. CD14 and toll-like receptor gene polymorphisms, country living, and asthma in adults. Am J Respir Crit Care Med. 2009;179(5):363-368.

37. Van Eerdewegh P, Little RD, Dupuis J, et al. Association of the ADAM33 gene with asthma and bronchial hyperresponsiveness. Nature. 2002;418(6896):426-430.

38. Söderhäll C, Marenholz I, Kerscher T, et al. Variants in a novel epidermal collagen gene (COL29A1) are associated with atopic dermatitis. PLoS Biol. 2007;5(9):e242.

39. Laitinen T, Polvi A, Rydman P, et al. Characterization of a common susceptibility locus for asthma-related traits. Science. 2004;304(5668): 300-304.

40. Vendelin J, Bruce S, Holopainen P, et al. Downstream target genes of the neuropeptide S-NPSR1 pathway. Hum Mol Genet. 2006;15(19): 2923-2935.

41. Pillai SG, Ge D, Zhu G, et al; ICGN Investigators. A genome-wide association study in chronic obstructive pulmonary disease (COPD): identification of two major susceptibility loci. PLoS Genet. 2009;5(3):e1000421.

42. Himes BE, Hunninghake GM, Baurley JW, et al. Genome-wide association analysis identifies PDE4D as an asthma-susceptibility gene. Am J Hum Genet. 2009;84(5):581-593.

43. Sugiura $H$, Ichinose M. Nitrative stress in inflammatory lung diseases. Nitric Oxide. 2011;25(2):138-144.

44. Smith FJ, Irvine AD, Terron-Kwiatkowski A, et al. Loss-of-function mutations in the gene encoding filaggrin cause ichthyosis vulgaris. Nat Genet. 2006;38(3):337-342.

45. Marenholz I, Nickel R, Rüschendorf F, et al. Filaggrin loss-of-function mutations predispose to phenotypes involved in the atopic march. J Allergy Clin Immunol. 2006;118(4):866-871.

46. Morar N, Cookson WO, Harper JI, Moffatt MF. Filaggrin mutations in children with severe atopic dermatitis. J Invest Dermatol. 2007;127(7): 1667-1672.

47. Palmer CN, Irvine AD, Terron-Kwiatkowski A, et al. Common lossof-function variants of the epidermal barrier protein filaggrin are a major predisposing factor for atopic dermatitis. Nat Genet. 2006;38(4): $441-446$. 
48. Palmer CN, Ismail T, Lee SP, et al. Filaggrin null mutations are associated with increased asthma severity in children and young adults. J Allergy Clin Immunol. 2007;120(1):64-68.

49. Ying S, Meng Q, Corrigan CJ, Lee TH. Lack of filaggrin expression in the human bronchial mucosa. J Allergy Clin Immunol. 2006;118(6): 1386-1388.

50. Hudson TJ. Skin barrier function and allergic risk. Nat Genet. 2006; 38(4):399-400.

51. Laing IA, de Klerk NH, Turner SW, et al; Perth Infant Asthma Follow-up Cohort. Cross-sectional and longitudinal association of the secretoglobin $1 \mathrm{~A} 1$ gene $\mathrm{A} 38 \mathrm{G}$ polymorphism with asthma phenotype in the Perth Infant Asthma Follow-up cohort. Clin Exp Allergy. 2009; 39(1):62-71.

52. Lee JH, Moore JH, Park SW, et al. Genetic interactions model among Eotaxin gene polymorphisms in asthma. J Hum Genet. 2008;53(10): 867-875

53. Levy H, Raby BA, Lake S, et al. Association of defensin beta-1 gene polymorphisms with asthma. J Allergy Clin Immunol. 2005;115(2): 252-258.

54. Min JW, Lee JH, Park CS, et al. Association of eotaxin-2 gene polymorphisms with plasma eotaxin-2 concentration. J Hum Genet. 2005;50(3):118-123.

55. Raby BA, Van Steen K, Lazarus R, Celedón JC, Silverman EK, Weiss ST. Eotaxin polymorphisms and serum total IgE levels in children with asthma. J Allergy Clin Immunol. 2006;117(2):298-305.

56. Sengler C, Heinzmann A, Jerkic SP, et al. Clara cell protein 16 (CC16) gene polymorphism influences the degree of airway responsiveness in asthmatic children. J Allergy Clin Immunol. 2003;111(3):515-519.

57. Zhang YG, Huang J, Zhang J, et al. RANTES gene polymorphisms and asthma risk: A meta-analysis. Arch Med Res. 2010;41(1):50-58.

58. Ober C, Hoffjan S. Asthma genetics 2006: the long and winding road to gene discovery. Genes Immun. 2006;7(2):95-100.

59. Vercelli D. Discovering susceptibility genes for asthma and allergy. Nat Rev Immunol. 2008;8(3):169-182.

60. Zhang J, Paré PD, Sandford AJ. Recent advances in asthma genetics. Respir Res. 2008;9:4.

61. Halapi E, Hakonarson H. Recent development in genomic and proteomic research for asthma. Curr Opin Pulm Med. 2004;10(1):22-30.

62. Hoffjan S, Nicolae D, Ober C. Association studies for asthma and atopic diseases: a comprehensive review of the literature. Respir Res. 2003;4:14.

63. Kabesch M. Candidate gene association studies and evidence for geneby-gene interactions. Immunol Allergy Clin North Am. 2005;25(4): 681-708.

64. Liggett SB. Genetics of beta 2-adrenergic receptor variants in asthma. Clin Exp Allergy. 1995;25 Suppl 2:89-94; discussion 95-96.

65. Martinez FD, Graves PE, Baldini M, Solomon S, Erickson R. Association between genetic polymorphisms of the beta2-adrenoceptor and response to albuterol in children with and without a history of wheezing. J Clin Invest. 1997;100(12):3184-3188.

66. Potter PC, Van Wyk L, Martin M, Lentes KU, Dowdle EB. Genetic polymorphism of the beta-2 adrenergic receptor in atopic and non-atopic subjects. Clin Exp Allergy. 1993;23(10):874-877.

67. Noguchi E, Yokouchi Y, Zhang J, et al. Positional identification of an asthma susceptibility gene on human chromosome 5q33. Am J Respir Crit Care Med. 2005;172(2):183-188.

68. Allen M, Heinzmann A, Noguchi E, et al. Positional cloning of a novel gene influencing asthma from chromosome 2q14. Nat Genet. 2003; 35(3):258-263.

69. Nicolae D, Cox NJ, Lester LA, et al. Fine mapping and positional candidate studies identify HLA-G as an asthma susceptibility gene on chromosome 6p21. Am J Hum Genet. 2005;76(2):349-357.

70. Zhang Y, Leaves NI, Anderson GG, et al. Positional cloning of a quantitative trait locus on chromosome $13 \mathrm{q} 14$ that influences immunoglobulin E levels and asthma. Nat Gen. 2003;34(2):181-186

71. Moffatt MF, Kabesch M, Liang L, et al. Genetic variants regulating ORMDL3 expression contribute to the risk of childhood asthma. Nature. 2007;448(7152):470-473.
72. Bisgaard H, Bønnelykke K, Sleiman PM, et al. Chromosome $17 q 21$ gene variants are associated with asthma and exacerbations but not atopy in early childhood. Am J Respir Crit Care Med. 2009;179(3): 179-185.

73. Galanter J, Choudhry S, Eng C, et al. ORMDL3 gene is associated with asthma in three ethnically diverse populations. Am J Respir Crit Care Med. 2008;177(11):1194-1200.

74. Leung TF, Sy HY, Ng MC, et al. Asthma and atopy are associated with chromosome 17q21 markers in Chinese children. Allergy. 2009;64(4):621-628.

75. Sleiman PM, Annaiah K, Imielinski M, et al. ORMDL 3 variants associated with asthma susceptibility in North Americans of European ancestry. J Allergy Clin Immunol. 2008;122(6):1225-1227.

76. Tavendale R, Macgregor DF, Mukhopadhyay S, Palmer CN. A polymorphism controlling ORMDL3 expression is associated with asthma that is poorly controlled by current medications. J Allergy Clin Immunol. 2008;121(4):860-863.

77. Ferreira MA, McRae AF, Medland SE, et al. Association between ORMDL3, IL1RL1 and a deletion on chromosome 17q21 with asthma risk in Australia. Eur J Hum Genet. 2011;19(4):458-464.

78. Rogers AJ, Raby BA, Lasky-Su JA, et al. Assessing the reproducibility of asthma candidate gene associations, using genome-wide data. Am J Respir Crit Care Med. 2009;179(12):1084-1090.

79. DeWan AT, Triche EW, Xu X, et al. PDE11A associations with asthma: results of a genome-wide association scan. J Allergy Clin Immunol. 2010;126(4):871-873. e9.

80. Hancock DB, Romieu I, Shi M, et al. Genome-wide association study implicates chromosome $9 \mathrm{q} 21.31$ as a susceptibility locus for asthma in mexican children. PLoS Genet. 2009;5(8):e1000623.

81. Milili M, Gauthier L, Veran J, Mattei MG, Schiff C. A new Groucho TLE4 protein may regulate the repressive activity of Pax 5 in human B lymphocytes. Immunology. 2002;106(4):447-455.

82. Sleiman PM, Flory J, Imielinski M, et al. Variants of DENND1B associated with asthma in children. $N$ Engl J Med. 2010;362(1) 36-44.

83. Franke A, McGovern DP, Barrett JC, et al. Genome-wide meta-analysis increases to 71 the number of confirmed Crohn's disease susceptibility loci. Nat Genet. 2010;42(12):1118-1125.

84. Mells GF, Floyd JA, Morley KI, et al. Genome-wide association study identifies 12 new susceptibility loci for primary biliary cirrhosis. Nat Genet. 2011;43(4):329-332.

85. Hirota T, Takahashi A, Kubo M, et al. Genome-wide association study identifies three new susceptibility loci for adult asthma in the Japanese population. Nat Genet. 2011;43(9):893-896.

86. Ferreira MA, Matheson MC, Duffy DL, et al; Australian Asthma Genetics Consortium. Identification of IL6R and chromosome 11q13.5 as risk loci for asthma. Lancet. 2011;378(9795):1006-1014.

87. Torgerson DG, Ampleford EJ, Chiu GY, et al; Mexico City Childhood Asthma Study (MCAAS), Gilliland FD; Children's Health Study (CHS) and HARBORS study, Burchard EG; Genetics of Asthma in Latino Americans (GALA) Study, Study of Genes-Environment and Admixture in Latino Americans (GALA2) and Study of African Americans, Asthma, Genes and Environments (SAGE), Martinez FD; Childhood Asthma Research and Education (CARE) Network, Weiss ST; Childhood Asthma Management Program (CAMP), Williams LK; Study of Asthma Phenotypes and Pharmacogenomic Interactions by Race-Ethnicity (SAPPHIRE), Barnes KC; Genetic Research on Asthma in African Diaspora (GRAAD) Study, Ober C, Nicolae DL. Meta-analysis of genome-wide association studies of asthma in ethnically diverse North American populations. Nat Genet. 2011;43(9):887-892.

88. Ober C, Tan Z, Sun Y, et al. Effect of variation in CHI3L1 on serum YKL-40 level, risk of asthma, and lung function. $N \mathrm{Engl} \mathrm{J} \mathrm{Med}$. 2008;358(16):1682-1691.

89. Weidinger S, Gieger C, Rodriguez E, et al. Genome-wide scan on total serum IgE levels identifies FCER1A as novel susceptibility locus. PLoS Genet. 2008;4(8):e1000166. 
90. Ramasamy A, Curjuric I, Coin LJ, et al. A genome-wide meta-analysis of genetic variants associated with allergic rhinitis and grass sensitization and their interaction with birth order. J Allergy Clin Immunol. 2011;128(5):996-1005.

91. Gudbjartsson DF, Bjornsdottir US, Halapi E, et al. Sequence variants affecting eosinophil numbers associate with asthma and myocardial infarction. Nat Genet. 2009;41(3):342-347.

92. Wilk JB, Chen TH, Gottlieb DJ, et al. A genome-wide association study of pulmonary function measures in the Framingham Heart Study. PLoS Genet. 2009;5(3):e1000429.

93. Hancock DB, Eijgelsheim M, Wilk JB, et al. Meta-analyses of genome-wide association studies identify multiple loci associated with pulmonary function. Nat Genet. 2010;42(1):45-52.

94. Repapi E, Sayers I, Wain LV, et al. Genome-wide association study identifies five loci associated with lung function. Nat Genet. 2010; 42(1):36-44.

95. Torgerson DG, Capurso D, Mathias RA, et al. Resequencing candidate genes implicates rare variants in asthma susceptibility. Am J Hum Genet. 2012;90(2):273-281.

96. Martinez FD, Holberg CJ, Halonen M, Morgan WJ, Wright AL, Taussig LM. Evidence for Mendelian inheritance of serum IgE levels in Hispanic and non-Hispanic white families. Am J Hum Genet. 1994;55(3):555-565.

97. Meyers DA, Postma DS, Panhuysen CI, et al. Evidence for a locus regulating total serum $\mathrm{IgE}$ levels mapping to chromosome 5 . Genomics. 1994;23(2):464-470.

98. Noguchi E, Shibasaki M, Arinami T, et al. Evidence for linkage between asthma/atopy in childhood and chromosome 5q31-q33 in a Japanese population. Am J Respir Crit Care Med. 1997;156(5): 1390-1393.

99. Postma DS, Bleecker ER, Amelung PJ, et al. Genetic susceptibility to asthma - bronchial hyperresponsiveness coinherited with a major gene for atopy. $N$ Engl J Med. 1995;333(14):894-900.

100. Xu J, Levitt RC, Panhuysen CI, et al. Evidence for two unlinked loci regulating total serum IgE levels. Am J Hum Genet. 1995;57(2): 425-430.

101. Baldini M, Lohman IC, Halonen M, Erickson RP, Holt PG, Martinez FD. A Polymorphism* in the 5' flanking region of the CD14 gene is associated with circulating soluble CD14 levels and with total serum immunoglobulin E. Am J Respir Cell Mol Biol. 1999;20(5): 976-983.

102. Gao PS, Mao XQ, Baldini M, et al. Serum total IgE levels and CD14 on chromosome 5q31. Clin Genet. 1999;56(2):164-165.

103. Koppelman GH, Reijmerink NE, Colin Stine O, et al. Association of a promoter polymorphism of the CD14 gene and atopy. Am J Respir Crit Care Med. 2001;163(4):965-969.

104. Leung TF, Tang NL, Sung YM, et al. The C-159T polymorphism in the CD14 promoter is associated with serum total IgE concentration in atopic Chinese children. Pediatr Allergy Immunol. 2003;14(4): 255-260.

105. Pacheco KA, Rose CS, Silveira LJ, et al. Gene-environment interactions influence airways function in laboratory animal workers. J Allergy Clin Immunol. 2010;126(2):232-240.

106. Ober C, Tsalenko A, Parry R, Cox NJ. A second-generation genomewide screen for asthma-susceptibility alleles in a founder population. Am J Hum Genet. 2000;67(5):1154-1162.

107. Woo JG, Assa'ad A, Heizer AB, Bernstein JA, Hershey GK. The -159 $\mathrm{C}->\mathrm{T}$ polymorphism of CD14 is associated with nonatopic asthma and food allergy. J Allergy Clin Immunol. 2003;112(2):438-444.

108. Heinzmann A, Dietrich H, Jerkic SP, Kurz T, Deichmann KA. Promoter polymorphisms of the CD14 gene are not associated with bronchial asthma in Caucasian children. Eur $J$ Immunogenet. 2003;30(5):345-348

109. Sengler C, Haider A, Sommerfeld C, et al; German Multicenter Allergy Study Group. Evaluation of the CD14 C-159 T polymorphism in the German Multicenter Allergy Study cohort. Clin Exp Allergy. 2003; 33(2):166-169.
110. Eder W, Klimecki W, Yu L, et al; Allergy And Endotoxin Alex Study Team. Opposite effects of CD 14/-260 on serum IgE levels in children raised in different environments. J Allergy Clin Immunol. 2005;116(3): 601-607.

111. Zambelli-Weiner A, Ehrlich E, Stockton ML, et al. Evaluation of the CD14/-260 polymorphism and house dust endotoxin exposure in the Barbados Asthma Genetics Study. J Allergy Clin Immunol. 2005; 115(6):1203-1209.

112. Namkung JH, Lee JE, Kim E, et al. An association between IL-9 and IL-9 receptor gene polymorphisms and atopic dermatitis in a Korean population. J Dermatol Sci. 2011;62(1):16-21.

113. Bottema RW, Kerkhof M, Reijmerink NE, et al. Gene-gene interaction in regulatory T-cell function in atopy and asthma development in childhood. J Allergy Clin Immunol. 2010;126(2):338-346, 346. e1-e10.

114. Bottema RW, Nolte IM, Howard TD, et al. Interleukin 13 and interleukin 4 receptor-alpha polymorphisms in rhinitis and asthma. Int Arch Allergy Immunol. 2010;153(3):259-267.

115. Reijmerink NE, Bottema RW, Kerkhof M, et al. TLR-related pathway analysis: novel gene-gene interactions in the development of asthma and atopy. Allergy. 2010;65(2):199-207.

116. De Lobel L, Geurts P, Baele G, Castro-Giner F, Kogevinas M, Van Steen K. A screening methodology based on Random Forests to improve the detection of gene-gene interactions. Eur J Hum Genet. 2010;18(10):1127-1132.

117. Chu JH, Weiss ST, Carey VJ, Raby BA. A graphical model approach for inferring large-scale networks integrating gene expression and genetic polymorphism. BMC Syst Biol. 2009;3:55.

118. Hawkins GA, Weiss ST, Bleecker ER. Clinical consequences of ADRbeta2 polymorphisms. Pharmacogenomics. 2008;9(3): 349-358.

119. Moore PE, Ryckman KK, Williams SM, Patel N, Summar ML, Sheller JR. Genetic variants of GSNOR and ADRB2 influence response to albuterol in African-American children with severe asthma. Pediatr Pulmonol. 2009;44(7):649-654.

120. Wechsler ME, Kunselman SJ, Chinchilli VM, et al; National Heart, Lung and Blood Institute's Asthma Clinical Research Network. Effect of beta2-adrenergic receptor polymorphism on response to longacting beta2 agonist in asthma (LARGE trial): a genotype-stratified, randomised, placebo-controlled, crossover trial. Lancet. 2009;374(9703): 1754-1764.

121. Taylor DR, Drazen JM, Herbison GP, Yandava CN, Hancox RJ, Town GI. Asthma exacerbations during long term beta agonist use: influence of beta(2) adrenoceptor polymorphism. Thorax. 2000;55(9): 762-767.

122. Bleecker ER, Postma DS, Lawrance RM, Meyers DA, Ambrose HJ, Goldman M. Effect of ADRB2 polymorphisms on response to longacting beta2-agonist therapy: a pharmacogenetic analysis of two randomised studies. Lancet. 2007;370(9605): 2118-2125.

123. Tantisira KG, Lasky-Su J, Harada M, et al. Genomewide association between GLCCI1 and response to glucocorticoid therapy in asthma. N Engl J Med. 2011;365(13):1173-1183.

124. Drazen JM, Yandava CN, Dubé L, et al. Pharmacogenetic association between ALOX5 promoter genotype and the response to anti-asthma treatment. Nat Genet. 1999;22(2):168-170.

125. Lima JJ, Zhang S, Grant A, et al. Influence of leukotriene pathway polymorphisms on response to montelukast in asthma. Am J Respir Crit Care Med. 2006;173(4):379-385.

126. Tantisira KG, Lake S, Silverman ES, et al. Corticosteroid pharmacogenetics: association of sequence variants in CRHR1 with improved lung function in asthmatics treated with inhaled corticosteroids. Hum Mol Genet. 2004;13(13):1353-1359.

127. Hawkins GA, Lazarus R, Smith RS, et al. The glucocorticoid receptor heterocomplex gene STIP1 is associated with improved lung function in asthmatic subjects treated with inhaled corticosteroids. J Allergy Clin Immunol. 2009;123(6):1376-1383. e7. 
128. Pascual M, Suzuki M, Isidoro-Garcia M, et al. Epigenetic changes in B lymphocytes associated with house dust mite allergic asthma. Epigenetics. 2011;6(9):1131-1137.

129. Isidoro-García M, Sanz C, García-Solaesa V, et al. PTGDR gene in asthma: a functional, genetic, and epigenetic study. Allergy. 2011; 66(12):1553-1562.

130. Balaci L, Spada MC, Olla N, et al. IRAK-M is involved in the pathogenesis of early-onset persistent asthma. Am J Hum Genet. 2007;80(6):1103-1114.

131. White JH, Chiano M, Wigglesworth M, et al; GAIN investigators, Vestbo J, Pillai SG. Identification of a novel asthma susceptibility gene on chromosome 1qter and its functional evaluation. Hum Mol Genet. 2008;17(13):1890-1903.

132. Mathias RA, Grant AV, Rafaels N, et al. A genome-wide association study on African-ancestry populations for asthma. J Allergy Clin Immunol. 2010;125(2):336-346. e4.

133. Noguchi E, Sakamoto H, Hirota T, et al. Genome-wide association study identifies HLA-DP as a susceptibility gene for pediatric asthma in Asian populations. PLoS Genet. 2011;7(7):e1002170.

134. Granada M, Wilk JB, Tuzova M, et al. A genome-wide association study of plasma total IgE concentrations in the Framingham Heart Study. J Allergy Clin Immunol. 2012;129(3):840-845. e21.
135. Pillai SG, Ge D, Zhu G, et al; ICGN Investigators. A genomewide association study in chronic obstructive pulmonary disease (COPD): identification of two major susceptibility loci. PLoS Genet. 2009;5(3):e1000421.

136. Cho MH, Boutaoui N, Klanderman BJ, et al. Variants in FAM13A are associated with chronic obstructive pulmonary disease. Nat Genet. 2010;42(3):200-202.

137. Cho MH, Castaldi PJ, Wan ES, et al; ICGN Investigators; ECLIPSE Investigators; COPDGene Investigators. A genome-wide association study of COPD identifies a susceptibility locus on chromosome 19q13. Hum Mol Genet. 2012;21(4):947-957.

138. Soler Artigas M, Wain LV, Repapi E, et al; Medical Research Council National Survey of Health and Development (NSHD) Respiratory Study Team, et al; SpiroMeta Consortium. Effect of five genetic variants associated with lung function on the risk of chronic obstructive lung disease, and their joint effects on lung function. Am J Respir Crit Care Med. 2011;184(7):786-795.

139. Imboden M, Bouzigon E, Curjuric I, et al. Genome-wide association study of lung function decline in adults with and without asthma J Allergy Clin Immunol. 2012;129(5):1218-1228.
International Journal of General Medicine

\section{Publish your work in this journal}

The International Journal of General Medicine is an international peer-reviewed open-access journal that focuses on general and internal medicine, pathogenesis, epidemiology, diagnosis, monitoring and treatment protocols. The journal is characterized by the rapid reporting of reviews, original research and clinical studies across all disease areas.

\section{Dovepress}

A key focus is the elucidation of disease processes and management protocols resulting in improved outcomes for the patient.The manuscript management system is completely online and includes a very quick and fair peer-review system. Visit http://www.dovepress.com/ testimonials.php to read real quotes from published authors. 